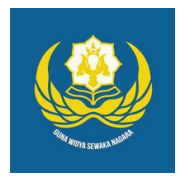

Jurnal Analogi Hukum

Journal Homepage: https://ejournal.warmadewa.ac.id/index.php/analogihukum

\title{
Peranan Badan Narkotika Nasional (BNN) Dalam Upaya Pencegahan Terhadap Tindak Pidana Narkotika
}

\author{
Ida Bagus Trisnha Setiaawan, Ida Ayu Putu Widiati dan Diah Gayatri Sudibya \\ Fakultas Hukum, Universitas Warmadewa, Denpasar, Bali-Indonesia \\ *trisnasetia@gmail.com
}

How To Cite:

Setiaawan, I. B. T., Widiati, I. A. P., \& Sudibya, D. G. (2020). Peranan Badan Narkotika Nasional (BNN) Dalam Upaya Pencegahan Terhadap Tindak Pidana Narkotika. Jurnal Analogi Hukum. 2(3). 361-365. Doi: https://doi.org/10.22225/ah.2.3.2517.361-365

\begin{abstract}
Narcotics is a substance that can make anyone who consumes it lose consciousness and various adverse effects can be caused from this drug because it contains both centric and semi-sentimental plants that affect brain performance until the disappearance of the pain that is felt but makes severe dependence, as for types and various types and this class of drugs has been attached to this Act. The formulation of the problem in this paper is how the duties and authority of the National Narcotics Agency in the act of criminal narcotics and what are the efforts of the National Narcotics Agency in the prevention of narcotics crimes. The research method used in this research is normative legal research; the author uses the main approach, namely the legislative approach to narcotics crime. By the National Narcotics Agency and enforcement practices and constraints that occur in eradicating narcotics crime faced by the National Narcotics Agency, the source of the author's legal material is obtained from a literature study of primary legal material and secondary legal material. The National Narcotics Agency is a non-ministerial government institution domiciled under the President and responsible to the President. The National Narcotics Agency has the duty and authority in the field of prevention and eradication and abuse of narcotics. The National Narcotics Agency encountered several obstacles in carrying out its duties, which were not sufficient operational costs, inadequate facilities and infrastructure, and a lack of community participation in helping the National Narcotics Agency to prevent narcotics crime.
\end{abstract}

Keywords: Role of National Narcotics Agency; Prevention; Narcotics Crime.

\begin{abstract}
Abstrak-Narkotika sebuah zat yang bisa membuat siapapun yang mengkonsumsinya menjadi hilang kesadaran serta berbagai efek buruk bisa ditimbulkan dari obat ini karena mengandung tanaman sentetis maupun semi sentetis yang berpengaruh pada kinerja otak sampai dengan menghilangnya rasa sakit yang dirasakan namun membuat ketergantungan parah, adapun jenis dan berbagai tipe serta golongan obat ini sudah dilampirkan dalam UU ini. Rumusan masalah dalam penulisan ini adalah bagaimanakah tugas dan wewenang Badan Narkotika Nasional dalam tindakpidana narkotika dan apa saja upaya Badan Narkotika Nasional dalam pencegahan tindak pidana narkotika. Metode penelitian yang digunakan dalam penelitian ini ialah penelitian hukum normatif, penulis menggunakan pendekatan utama yaitu pendekatan perundang-undangan terhadap tindak pidana narkotika. Badan Narkotika Nasional ,praktik pertahanan bersama kendala-kendala yang berlangsung. Dalam pemberantasan tindak pidana narkotika yang dihadapi oleh Badan Narkotika Nasional, sumber bahan hukum penulis diperoleh sejak studi kepustakaan, melalui bahan hukum primer dan bahan hukum sekunder. Badan Narkotika Nasional ialah lembaga pemerintahan bukan kementerian mempunyai berpangkat di bawah Presiden serta bertanggung jawab kepada Presiden. Badan Narkotika Nasional mempunyai tugas dan kewenangan dalam bidang pencegahan dan pemberantasan dan penyalahgunaan narkotika. BNN menemui beberapa kendala dalam menjalankan tugasnya yaitu biaya operasional yang belum tercukupi, adanya faktor sarana dan prasarana yang kurang memadai, dan kurangnya peran serta masyarakat membantu BNN untuk mencegah tindak pidana narkotika.
\end{abstract}

Kata kunci: Peran BNN; Pencegahan; Tindak Pidana Narkotika

\section{Pendahuluan}

Masyarakat dunia dan masyarakat
Indonesia sedang menghadapi gejolak permasalahan dalam tingkat waspada terkait penyalahgunaan obat bahaya terlarang secara 
tidak sah. Disatu sisi narkotika adalah obat atau bahan yang biasa dimanfaatkan untuk bidang pengobatan atau pelayanan kesehatan dan pengembangan ilmu pengetahuan alam serta akan tetapi disatu sisi narkotika dan psikotropika dapat menimbulkan berbagai macam kerugian apabila digunakan dalam hal negatif yang berpotensi membuat ketergantungan berat yang sangan berbahaya bagi diri sendiri yang membuat masa depan hancur sampai dengan bisa terjadinya kematian tentu bukan hal yang diinginkan (Gayo, 2014).

Menurut Undang-Undang RI nomor 35 Tahun 2009 Pasal 1 ayat (1), Narkotika sebuah zat yang bisa membuat siapun yang mengkonsumsinya menjadi hilang kesadaran serta berbagai efek buruk bisa ditimbulkan dari obat ini karena mengandung tanaman sentetis maupun semi sintetis yang berpengaruh pada kinerja otak sampai dengan menghilangnya rasa sakit yang dirasakan namun membuat ketergantungan parah, adapun jenis dan berbagai tipe serta golongan obat ini sudah dilampirkan dalam UU ini.

Demi penyempurnaan dibidang hukum yang khusus mengatur mengenai narkotika, dan dalam menunjukkan keseriusannya dalam mencegah dan memberantas narkotika, pemerintah memformat Badan Narkotika Nasional (BNN) yang merupakan Lembaga pemerintah non kementerian yang berdomisili dibawah dan bertanggung jawab pada presiden yang ada disetiap provinsi dan kabupaten atau kota. BNN mempunyai tugas yaitu menjalankan amanat pemerintah dalam bagian pencegahan, penanggulangan atas banyaknya penyebaran gelap psikotropika, precursor, serta subjek adiktif lainnya kecuali subjek adiktif untuk tembakau serta alcohol.

Banyaknya regulasi berlakukan tentang aturan mengenai zat terlarang tepi tidak bisa meredakan msalah yang terjadi yang merusak masa depan generasi muda saat ini. Sanksi berat pun sudah dijatuhkan guna menekan angka peredaran namun banyak pula yang tidak mengindahkannya malah semakin terjadinya operasi di daerah guna memperluas sasaran korban narkotika (Kaligis \& Associates, 2002).

Dikeluarkannya UU No. 35 Tahun 2009 memberikan kewenang bagi badan narkotika nasional untuk melakukan penyelidikan dan penyidikan dalam kasus penyalahgunaan zat bahaya hadirnya badan nasional ini agar bisa mempercepat proses guna membantu korban dalam perkara zat berbahaya ini. Juga di harapkan peraturan ini bisa meberikan sanksi yang tepat guna keadilan bersama. Mulai dari sanksi terhadap bandar maupun pengguna.

Maraknya peredaran barang haram ini tidak hanya bisa dihentikan oleh satu atau dua orang saja melainkan seluruh lapisan masyarakat, tidak hanya penegak yang harus menghentikan jalan masuk barang haram ini namun perlunya bantuan masyarakat guna menegakkan regulasi yang telah ada agar mempunyai wibawa dalam hukum itu sendiri. UU No 35 Tahun 2009 sangat tepat dikeluarkan guna menjerat orang-orang perusak generasi muda saat ini. Fungsi BNN harus mendapat dorongan masyarakat agar bisa berjalannya proses hukum dalam penegakan penyalahgunaan obat terlarang.

Hasil penelitian (Suparta, 2015) mengungkapkan 2 cara dalam upaya penanggulangan Narkoba yaitu Upaya Preventif berupa strategi dan fasiltas untuk screening awal bagi pengedar dan pengguna narkoba dan Upaya represif berupa Pengamanan Barang Bukti dan pengamanan terhadap pelaku penyelundup narkotika atau kurir narkotika, Menindak Pelaku Yang Terbukti Melakukan Penyelundupan Narkotika. Penelitian lainya juga menemukan hasil yang sama, Hasil penelitian (Yudha, Dewi, \& Sujana, 2019) menyebutkan Upaya kepolisian dalam menanggulangi peredaran dan penyalahgunaan narkotika di wilayah hukum Polres Bangli yaitu Melakukan tindakan awal (pre-emtif), Tindakan preventif, Melakukan tindakan penegakan hukum (refresif) bagi orang-orang yang terbukti mengedarkan dan menggunaan narkoba dan Melakukan kerjasama dengan instansi terkait seperti Badan Narkotika Kabupaten (BNK). Dari kedua penelitian diatas, dapat disimpulkan meskipun menggunakan metode yang sama, namun di setiap daerah memiliki hasil yang berbeda.

Berdasarkan uraian latar berlakang masalah tersebut, maka dirumuskan beberapa masalah yang dianalisis dalam penelitian ini, yaitu tugas dan wewenang Badan Narkotika Nasional dalam tindak pidana narkotika dan upaya pencegahan oleh Badan Narkotika Nasional terhadap tindak pidana narkotika. Penelitian ini bertujuan Untuk mengetahui serta mempelajari secara mendalam tugas dan wewenang Badan Narkotika Nasional terhadap tindak pidana narkotika dan mengetahui upaya pencegahan yang dihadapi BadannNarkotika Nasional terhadap tindak pidana narkotika.

\section{Metode}

Penelitian ini menggunakan metode penelitian hukum normatif. Dimana metode ini 
mengkaji aspek teori, struktur atau komposisi, perbandingan, penjelasan umum dan penjelasan pada tiap pasal. Pendekatan masalah yang digunakan adalah pendekatan perundangundangan mengenai penyalahgunan zat atau obat berbahaya oleh badan terkait dan kendala masalah yang dihadapi dalam pemebrantasan peredaran barang haram ini.

Penggunaan sumber bahan hukum di dalam proses penelitian sangat tergantung pada bahan hukum dibawah diantarnya Bahan hukum primer meliputi :

- Kitab Undang-Undang Hukum Pidana

- Undang-Undang Nomor 35 Tahun 2009 Tentang Narkotika

- Peraturan Presiden Nomor 23 Tahun 2010 tentang Badan Narkotika Nasional

Bahan hukum sekunder adalah bahan hukum yang bawaan mengartikan bahan hukum terkait, dimana bahan hukum sekunder berupa buku literatur, produk karya sarjana untuk memperlaju wawasan penulis, mengenai bidang penulisan.

Teknik pengumpulan bahan hukum ini diperoleh melalui metode pencegahan yaitu dengan cara membaca, mengutip, dan mencatat bahan-bahan hukum yang berhubungan dengan masalah yang digunakan. Dan metode pengumpulan yang digunakan adalah penelitian kepustakaan (library research), yang melakukan penelitian terhadap berbagai sumber bacaan, yaitu artikel-artikel, buku dan internet yang berhubungan dengan penelitian skripsi ini.

Analisis bahan hukum, setelah penulis mengumpulkan bahan-bahan hukum, lalu kemudia dapat dianalisis dengan interpretasi hukum secara sistematis yang kemudian disajikan dalam bentuk deskriptif analisis, untuk memberikan gambaran yang selengkaplengkapnya tentang upaya pencegahan dilakukan badan terkait guna mengetahui fungsi dan kewenangan BNN guna pencegahan serta menekan penggunaan dari obat berbahaya ini (Sunggono, 1997).

\section{Hasil Penelitian Dan Pembahasan}

Tugas Dan Wewenang Badan Narkotika Nasional Dalam Upaya Pencegahan Terhadap Tindak Pidana Narkotika.

Adapun tugas dari Badan Narkotika Nasional menurut Peraturan Presiden Nomor 23 Tahun 2010 tentang Badan Narkotika Nasional yaitu : a. Mampu membuat dan melaksanakan kebijakan nasional tentang pemberantasan dan pencegahan penyalahgunaan serta peredaran gelap narkotika

b. Memberantas guna mencegah peredaran penyalahgunaan narkotika

c. Berkoordinasi dengan Kepala Kepolisian Negara Republik Indonesia perihal pencegahan dan pemberantasan serta peredaran gelap narkotika

d. Meningkatkan kemampuan Lembaga rehabilitasi medis dan sosial pecandu narkotika, baik yang diselenggarakan oleh masyarakat maupun pemerintah

e. Mampu memberdayakan masyarakat dalam hal pencegahan penyalahgunaan dan peredaran gelap narkotika

f. Mengarahkan,memantau, serta meningkatkan kegiatan di masyarakat dalam hal pencegahan penyalahgunaan serta peredaran gelap narkotika

g. Menjalin kerja sama bilateral dan multilateral, baik regional maupun internasional, untuk mencegah serta memberantas peredaran gelap narkotika

h. Mengembangkan laboratorium narkotika dan precursor narkotika

i. Melakukan administrasi penyelidikan dan penyidikan terhadap perkara penyalahgunaan dan peredaran gelap narkotika, dan

j. Membuat laporan tahunan tentang pelaksanaan tugas dan wewenang.

Berdasarkan Undang-Undang Nomor 35 Tahun 2009 tentang narkotika, Badan Narkotika Nasional diberi kewenangan besar, salah satunya yaitu mencegah dan memberantas penyalahgunaan serta peredaran gelap narkotika dan prekursor narkotika, selain itu Badan Narkotika Nasional juga berkuasa serta berhak melakukan penyelidikan, penyidikan penyalahgunaan narkotika serta peredaran gelap narkotika dan prekursor narkotika.

\section{Upaya Pencegahan Oleh Badan Narkotika Terhadap Tindak Pidana Narkotika}

Mendapat julukan sebagai tempat destinasi terindah di dunia membuat bali mendapatkan kunjungan wisatawan asing maupun lokal dalam setiap tahunnya meningkatkan pariwisata di Bali, namun dari berbagai dampak baik yang 
ditimbulkan ini terdapat pula berbagai jenis kerugian yang dialami karena tidak sedikit wisatawan membawa peredaran barang haram atau nakotika yang di negara Indonesia sangat dilarang penyebarannya. Adanya badan narkotika nasional sangat membawa pengaruh baik dalam kasus perkara narkotika karena BNN sangat mengutamakan mencegahan guna menanggulangi penyebaran lebih luas obat terlarang ini. Sosialisasi tidak henti-hentinya dilakukan setiap tahun di daerah- daerah, sekolah dan lain-lain guna menanggulangi bahaya narkotika itu sendiri.

Inpres tahun 2018 untuk kepala BNN agar dapat melibatkan fungsi masyarakat serta berbagai sektor usaha sesuai dengan peraturan yang sudah ada guna menekat penyebaran barang haram ini.

Dan khususnya untuk Kepala Badan Narkotika Nasional (BNN), presiden memberi intruksi guna :

a. Mengoordinasikan kementrian serta Lembaga untuk melakukan Rencana Aksi Nasional P4GN Tahun 2018-2019,

b. Mengoordinasikan pemerintah daerah Bersama Menteri dalam Negeri dalam melaksanakan Rencana Aksi Nasional P4GN Tahun 2018-2019,

c. Melakukan pemantauan dan evaluasi Bersama Menteri PPN atau Kepala Bappenas perihal tentang pelaksanaan Rencana Aksi Nasional P4GN Tahun 20182019.

Masih dalam kategori Bidang Pencegahan, juga ada rencana aksi nasional berarti Pelaksanaan tes urine kepada seluruh pegawai Aparatur Sipil Negara, termasuk calon Aparatur Sipil Negara,Pembentukan Satuan Tugas atau Relawan Anti Narkotika dan Prekursor Narkotika serta Pelaksanaan pelatihan kader pemuda anti Narkotika dan Prekursor Narkotika.

Dalam Bidang Pemberantasan, beberapa rencana aksi nasional telah disajikan ialahPenyelamatan aset yang berasal dari tindak pidana Narkotika dan Prekursor Narkotika dan atau tindak pidana pencucian uang terkait Narkotika dan Prekursor Narkotika,Pengawasan Lembaga Pemasyarakatan Narkotika serta Pembentukan rumah tahanan Narkotika.

Berarti di sebuah kehidupan tentu kita tidak mengingikan sebuah penderitaan apalagi penderitaan yang muncul karena kesalahan dalam diri sendiri yang tidak bisa menekan keinginan untuk mengkonsumsi barang haram atau obat terlarang ini, namun hal ini dapat di antisipasi dengan berbagai cara yang mudah dan meyehatkan yaitu cara yang pertama dengan mengendalikan emosi contohnya lakukan apa yang bisa membuat senang hati dan pikiran agar bisa membawa hawa positif bagi tubuh, kedua dengan cara berpikir kreatif seperti latihlah diri sendiri agar bisa melakukan seuatu hal yang berguna bagi diri sendiri maupun orang lain. Walaupun sudah adanya BNN namun apabila dalam diri tidak terlebih dahulu tidak bisa mengantisipasi bahaya narkotika maka semuaitu tidak ada gunanya. khususnya dalam rangka deteksi dini serta Pencegahan, Pemberdayaan Masyarakat Bahaya Penyalahgunaan Narkoba, pada tanggal 27 September 2018 BNN Provinsi Bali bersinergi untuk Melaksanakan Test Urine, tentang hal sepak terjang pemberian informasi serta konfirmasi hadapan siswa-siswi, memasarkan sosialisasi terhadaps para siswa tentang UU no 35 Tahun 2009 dan InPres nomor 6 tahun 2018, memplopori oleh Kasi Pemberdayaan Masyarakat BNN Provinsi Bali tentang hal yang dipersembahkam Berpikir kreatif sememangnya berlatih berpikir kreatif sama seperti melatih diri dalam melakukan tindakan atau perbuatan misalnya berlatih berbuat baik maka akan terbiasa semakin baik. Berlatih percaya diri maka terbiasa yakin dengan seorangang Perlu diperhatikan bahwa berpikir kreatif atau imajinatif bukanlah bakat khusus yang hanya dimiliki beberapa orang saja karena sejak dilahirkan manusia .

Adapun beberapa Rencana Aksi Nasional yang akan dilakukan dibidang pencegahan yaitu :

a. Melakukan sosialisasi tentang bahayanya narkotika dan prekursor narkotika serta memberi infomasi tentang P4GN kepada prajurit TNI, anggota polri dan aparatur sipil negara, dengan penanggung jawab BNN, Kementerian dalam Negeri dan Pendayagunaan Aparatur Negara dan Reformasi Birokrasi (PANRB).

b. Menyelenggarakan Hari Remaja Internasional ditingkat pusat dan provinsi

c. Mendirikan lima Pusat Informasi Edukasi Narkotika, Psikotropika dan Zat Adiktif (PIE NAPZA) di lima wilayah yang rentan dan rawan narkotika dan prekursor narkotika.

Dan ada juga rencana aksi nasional lainnya yang masih dibidang pencegahan yaitu : melakukan pelaksanaan tes urine kepada seluruh pegawai atau calon aparatur sipil 
negara, membentuk satuan tugas atau relawan anti narkotika, melakukan pelatihan kader pemuda anti narkotika.

Adapun rencana aksi nasional dibidang pemberantasan yaitu sebagai berikut : menyelamatkan aset yang berasal dari tindak pidana narkota alias tindak pidana pencucian uang tersangkut narkotika, melakukan pengawasan Lembaga pemasyarakatan narkotika, dan membentuk rumah tahanan narkotika.

Disamping itu kendala yang dialami dari badan terkait pencegahan bahaya obat terlarang itu terdapat dalam dana operasional yang belum belum bisa terpenuhi guna penyelidikan lebih lanjut. Juga dikarenakan alat pengintaian kurang canggih daripada yang dimiliki oleh jaringan narkoba.

\section{Simpulan}

Dari pembahasan yang telah diuraikan diiatas, maka penulis dapat menarik kesimpulan Badan Narkotika Nasional atau BNN suatu Lembaga Pemerintah Non Kementerian (LPNK) Indonesia mengantongi amanat dan kewajiban melaksanakan amanat pemerintah dibidang pencegahan, pemberantasan penyalahgunaan dan peredaran gelap narkotika, psikotropika, prekursor dan bahan adiktif lainnnya kecuali bahan adiktif untuk tembakau dan alcohol

Untuk menanggulangi tindak pidana narkotika, BNN mengutamakan bidang pencegahan. Dalam bidang ini BNN sudah melakukan pencegahan disemua lingkungan baik di instansi pemerintah, masyarakat, keluarga maupun organisasi, dan hamper disemua lingkungan tersebut sudah diberi pelatihan tentang bahaya narkotika. Selama menjalankan tugas dibidang pencegahan dan pemberantasan terkait tindak pidana narkotika, BNN menemui beberapa kendala yaitu BNN terkendala oleh biaya operasional penyelidikan yang besar yang sampai saat ini belum tercukupi, dan adanya faktor sarana prasarana yang kurang memadai, dan kurangnya peran serta masyarakat dalam membantu BNN untuk mencegah terjadinya penyalahgunaan narkotika.

Kepada pemerintah dan beserta jajarannya agar bisa memfasilitasi permasalahan yang ditemukan dalam upaya pencegahan tindak pidana narkotika, contohnya seperti mengibahkan alat- alat dalam menanggulangi tindak pidana penyelundupan narkotika, dan lebih menggerakan sosialisasi tentang bahayanya narkotika dikalangan remaja seperti disekolah dan universitas.

Bagi masyarakat dihimbau agar ikut berperan aktif dalam menanggulangi penyebaran berbagai jenis narkotika berbahaya karena dapat memicu berbagai kejadian buruk yang tidak diinginkan. Pencegahan dalam diri sendiri adalah hal utama yang diharapkan karena semua yang baik berawal dari diri sendiri yang ingin menjadi pribadi yang positif.

\section{Daftar Pustaka}

Gayo, A. A. (2014). Pemberantasan Peredaran Gelap Narkotika. Jakarta: Pusat Pengkajian, Pengolahan Data dan Informasi (P3DI).

Kaligis, O. C., \& Associates. (2002). Narkoba dan Peradilannya di Indonesia, Reformasi Hukum Pidana Melalui Perundangan dan Peradilan. Alumni, Bandung. Bandung: Alumni. Retrieved from http:// bpsdm.kemenkumham.go.id/elibrary/ index.php? $\mathrm{p}=$ show detail\&id $=2452 \&$ keywords $=$

Kitab Undang-Undang Hukum Pidana

Peraturan Presiden Nomor 23 Tahun 2010 tentang Badan Narkotika Nasional

Sunggono, B. (1997). Metodologi Penelitian Hukum. Jakarta: PT Raja Grafindo Persada.

Suparta, I. K. (2015). Upaya Badan Narkotika Nasional (Bnn) Dalam Menanggulangi Tindak Pidana Penyelundupan Narkotika Oleh Warga Negara Asing (Study Di Badan Narkotika Nasional Provinsi Bali). Jurnal Hukum Universitas Brawijaya, Juni, 1-13. Retrieved from http:// hukum.studentjournal.ub.ac.id/ index.php/hukum/article/view/1176

Undang-Undang Nomor 35 Tahun 2009 Tentang Narkotika

Yudha, I. G. D., Dewi, A. A. S. L., \& Sujana, I. N. (2019). Upaya Kepolisian Dalam Menanggulangi Peredaran dan Penyalahgunaan Narkotika Di Wilayah Hukum Polres Bangli. Jurnal Analogi Hukum, 1(3), 311-316. Retrieved from https://doi.org/10.22225/ ah.1.3.1778.311-316 